\title{
Interrelationship of of Matrix metalloproteinase-13 and Elastase Expression in Human Gingiva with Chronic Periodontitis Associated to Type 2 Diabetes Mellitus
}

\author{
Hyun-Kyu Park, Jae-Mok Lee
}

School of Dentistry, Kyungpook National University

\section{Introduction}

Diabetes mellitus(DM) is disease resulted from insufficiency of insulin production or from reduction of tissue response to circulating insulin and symptoms such as organ system damage, immune imparement can expressed by hyperglycemia. Especially, type 2 diabetes mellitus is related with latter reason and predominant to adult patient and occupies 90\% of overall DM.

From 1960s, there has been discussions between diabetes mellitus and degree of periodontitis. Many studies reported diabetes mellitus increases the susceptibility to oral infection including periodontitis. Although DM itself doesn't cause periodontitis, periodontal disease progresses more rapidly and leads to more tooth losses in patients with poorly controlled blood glucose ${ }^{1-3)}$.
In chronic hyperglycemia, advanced glycation end-products(AGEs) is produced and this material induce secretion of pro-inflammatory cytokine such as Interleukin-1, Tumor Necrosis Factor $-\alpha$ by binding to macrophage and blood vessel endothelial cells ${ }^{4-6)}$. And it is assumed that increased infection susceptibility by declined function of polymorphonuclear leukocyte (PMNL), reduction of collagen production by fibroblast, periodontal ligament cell, blood vessel disorder, change of sulcular fluid and subgingival microorganism, hereditary tendency contribute to the disease. Nelson et al. $^{7)} \mathrm{re}^{-}$ ported that type 2 diabetes mellitus patient shows 2.6 times higher incidence of periodontitis than normal person and Papupanou et al. ${ }^{8)}$ reported that diabetes mellitus increases risk of periodontitis twice, regardless of local contributing factor such as calculus.

And inversely, a few studies reported insulin

\footnotetext{
* Correspondence author : Jae-Mok Lee, Department of Periodontology, School of Dentistry, Kyungpook National University, 50 Samduk-Dong, Jung-Gu, Daegu, 700-422, South Korea
} 
function can be interrupted by inflammatory mediator of periodontitis. Joshi et al. ${ }^{9)}$ reported that inflammatory mediator such as $\mathrm{TNF}-a$, $\mathbb{L}-6$ and $\mathrm{IL}-1 \beta$ can increase insulin resistance in conditions of

acute infectious disease resulting in abnormal glucose, lipid metabolism ${ }^{10)}$. And more direct harmful effect of periodontitis on diabetes mellitus was demonstrated by Taylor et $\mathrm{al}^{11}$. They reported that severe periodontitis patient with initially favorable blood-sugar level shows 6 times more aggravated glucose control after 2 years than patient with initial periodontitis.

Periodontitis is infectious disease characterized by destruction of tooth supporting tis sue and this is degradation of tissue collagen component by matrix metalloproteinases $(\mathrm{MMPS})^{12)}$.

Basically, Matrix metalloproteinases(MMPs) is a family of zinc-dependent endopeptidases which can degradate all of extracellular matrix component ${ }^{13,14}$. $M M P$ is primarily in charge of matrix remodeling and degradation in pathological condition such as rheumatoid arthritis, osteoarthritis, dermal photo aging, periodontitis but also play important role in embryonic development, tooth development, wound healing $^{15,16)}$.

Currently, MMP gene family contains 24 members which can be divided into collagenases, gelatinaes, stromelysins, matrilysin and membrane- type MMPs(MT-MMPs) subgroup. As a principal proteinase undertaking cleavage of native fibrillar collagen in extracellular space, collagenase superfamily includes collagenase $-1(\mathrm{MMP}-1)$, neutrophil collagenase $(\mathrm{MMP}-8)$ and collagenase $-3(\mathrm{MMP}-13)$.

MMP-13 is expressed by chondrocyte, fibroblast, epithelial cell, several tumor cells and exceptionally has very large substrate specificity than other MMPs. It can degradate not only fibrillar type I, II,III collagen but also VI, IX, $\mathrm{X}$ collagen, gelatin, tenascin-C, fibronectin and proteoglycan core protein ${ }^{17,18)}$. Several studies reported the relationship between MMP-13 and gingival inflammation. Uitto et al. ${ }^{19)}$ reported that $\mathrm{MMP}-13$ was revealed to exist in epithelium facing gingival pocket during chronic inflammation and expressed by gingival fibroblast and to be engaged in invasion of pocket epithelium to periodontal connective tissue.

Wahlgren et al. $^{20)}$ demonstrated that MMP-8 and $\mathrm{MMP}-13$ produced by plasma cell in the area of chronic inflammation and neoplastic growth are involved in bone organic matrix destruction and Kiili et al. ${ }^{21)}$ confirmed close relationship between $\mathrm{MMP}-8, \mathrm{MMP}-13$ with gingival, bleeding index in chronic periodontitis patient.

As a principal proteolytic component of neutrophil, elastase was known as a marker of nonspecific degradation of elastin, collagen and proteoglycan which is important molecules in function and structure. And many studies reported that elastase is related to gingival inflammation in the analysis of GCF.

In experimentally induced gingivitis and periodontitis, increased expression of elastase which is one of serine proteinases was shown. Eley et al. ${ }^{22)}$ reported inflammation stage can be determined by analysis of GCF elastase. Jin et al. ${ }^{23)}$ demonstrated that the activity level of IL-8 and granulocyte elastase decreased with positive correlation when co-infection of B.forsythus, P.gingivalis, P.intermedia and T.denticola was reduced after scaling and root 
planing. Chen ${ }^{24)}$ demonstrated positive correlation of MMP-8 and elastase through GCF assay in chronic periodontitis patient.

As described above, several studies reported the increased expression of MMP-13 and elastase in periodontitis patient, but there is limited data on the expression of $\mathrm{MMP}-13$, elas tase and relationship between two proteins in patient with chronic periodontitis related to type 2 diabetes mellitus.

The purpose of this study is to exam the difference of pathologic condition by comparing expression phase of $\mathrm{MMP}-13$ and elastase and to find out the relationship of two proteins in gingival tissue of chronic periodontitis patient and those with type 2 diabetes mellitus.

\section{Materials and Methods}

\section{Study population and Tissue sampling}

As described in our previous study ${ }^{25)}$, population consisted of 8 patients with type 2 diabetes and chronic periodontitis, 8 patients with chronic periodontitis, and 8 healthy individuals. Marginal gingival tissue samples were obtained by internal bevel incision at the time of periodontal surgery (including surgical crown lengthening) or tooth extraction and informed consent was obtained from all of the participants before the surgery.

According to the patient's systemic condition (age, sex, blood glucose level, obesity, smoking) and clinical criteria of gingiva (Sulcus bleeding index value ${ }^{26)}$, probing depths) and radiographic evidences of bone resorption, each gingival sample was divided into the three groups. Group 1 (normal, $n=8$ ) is clinically healthy gingiva without bleeding and no evidence of bone resorption or periodontal pockets, obtained from systemically healthy 8 patients. Group 2 (chronic periodontitis, $\mathrm{n}=8$ ) is inflamed gingiva from patients with chronic periodontitis. The diagnosis of chronic periodontitis was established on the basis of clinical and radiographic criteria (bone resorption) according to the classification system for periodontal disease and condition ${ }^{27}$. All patients in group 2 were systemically healthy and had more than one periodontal pockets $\geq 5 \mathrm{~mm}$ and at least one pocket with $\geq 4 \mathrm{~mm}$ loss of attachment. All gingival samples were obtained from teeth with probing depth $\geq 5 \mathrm{~mm}$, swelling of the marginal gingiva, and bleeding corresponding to Gingival sulcus bleeding indexes 3 according to Mühlman and Son26). Group 3 (chronic periodontitis \& type $2 \mathrm{DM}, \mathrm{n}=8$ ) is inflamed gingiva from patients with chronic periodontitis associated with type 2 diabetes. Patients in group $2 \& 3$ have similar periodontal condition, but patients in group 2 were systemically healthy and patients in group 3 had type 2 diabetes diagnosed at least 6 months ago and blood glucose level was $200 \mathrm{mg} / \mathrm{dl}$ on 2-hour postprandial and under medication. Gingival sample were obtained by similar way described above.

Following surgery, excised tissue specimens were immediately placed on liquid nitrogen and subsequently frozen $\left(-70^{\circ} \mathrm{C}\right)$.

\section{Protein Isolation and Western blotting}

For Western blotting, as previously described technique by Kang et al. ${ }^{25)}$, frozen tissues were homogenized in RIPA lysis buffer (10 mM EDTA, 
0.15M $\mathrm{NaCl}$ ) with 1:30 diluted protease inhibitor cocktail (Roche, German) according to Cho's method ${ }^{28)}$. The lysates were sonicated 3 times for 10 seconds and centrifuge at $12,000 \mathrm{~g}$ for 15 minutes. Protein concentrations of $\mathrm{su}^{-}$ pernatant were routinely determined by a Braford protein asssay (Bio-Rad, USA) using BSA as standard.

Lysates were boiled in SDS samples buffer (1M Tris-Cl (pH6.8), 40\% glycerol, 8\% SDS, 2\% mercapto-ethanol, 0.002\% Bromophenole blue). Prepared samples were separated by $15 \%$ sodium dodecyl sulfate (SDS) - polyacrylamide gels and transferred to a polyvinylidene difluride membrane.

The membranes were subsequently blocked in Tris-buffered saline (TBS) containing 5\% powdered milk and 1\% BSA for 1 hour, and then incubated with polyclonal anti-MMP-13 antibodies, anti-elastase antibodies (Santa Cruz Biotechnology, USA) for 1.5 hours at room temperature.

The membranes were washed (five times for 5 minutes with Tween 20) and incubated with a horseradish peroxidase(HRP)-conjugated donkey anti-gout secondary antibody (diluted 1: 2000 in TBS)(Santa Cruz Biotechnology, USA). for 1 hour at room temperature. After additional washing (five times for 5 minutes with Tween 20) the Western blot procedure was completed with an ECL Plus development kit (Amsterdam, Beckinghamshire, U.K.)

The quantification analysis of $\mathrm{MMP}-13$ and elastase expression was performed using a densitometer (Scion Image $\beta$ 4.02, Scion Corporation, USA). After normalization to $\beta$ -actin $\left(\right.$ Abcam $^{\circledR}$ U.K.) in each sample, MMP-13 and elastase expression levels were showed as a ratio of $\mathrm{MMP}$ or elastase/ $\beta$-actin and the differences of density between 3 groups were determined.

\section{Statistical Analysis of the Western blot results}

All data were presented as means \pm standard deviation and the results were statistically analyzed. The MMP-13 and elastase expression levels among each 3 groups were compared using one way ANOVA followed by Tukey's test. $P$ value $<0.05$ was considered to statistically significant.

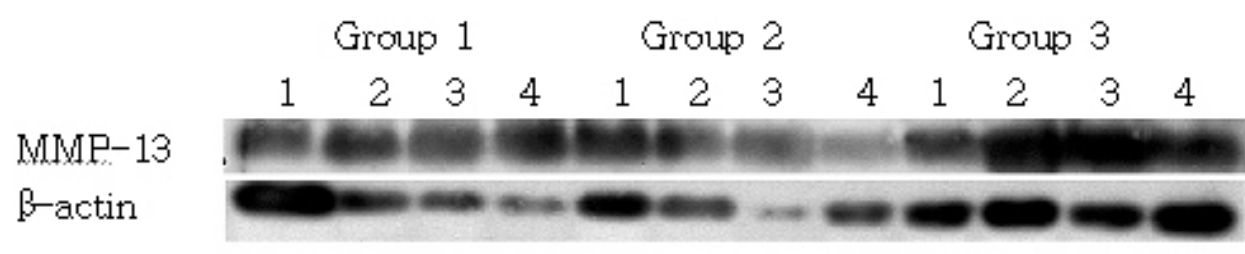

Figure. 1. The MMP-13 expression levels showing 4 representative samples in each group. The MMP-13 expression levels corresponding to molecular weight $55 \mathrm{kDa}$ were shown in all samples including healthy gingiva and the expression levels of MMP-13 were increased in group 3 than group 1 and group 2. In order to quantify the MMP-13 levels, $\beta$-actin levels were also performed.

Group 1 : healthy gingiva from systemically healthy person

Group 2 : inflammed gingiva from patient with chronic periodontitis

Group 3 : inflammed gingiva from patient with chronic periodontitis and type 2 DM 
Table 1. The MMP-13 expression intensity was normalized by $\beta$-actin intensity to quantify the expression levels of $M M P-13$ and the value were presented as a ratio of MMP-13/ $\beta$-actin

\begin{tabular}{cccc}
\hline Sample & Group 1 & Group 2 & Group 3 \\
\hline 1 & 0.752 & 0.765 & 0.792 \\
2 & 0.786 & 1.013 & 1.028 \\
3 & 0.842 & 0.765 & 1.063 \\
4 & 0.654 & 0.735 & 0.846 \\
5 & 0.704 & 0.942 & 1.030 \\
6 & 0.808 & 0.680 & 1.084 \\
7 & 0.869 & 0.848 & 1.273 \\
8 & 0.953 & 0.794 & 1.240 \\
\hline Mean \pm SD & $0.796 \pm 0.095$ & $0.818 \pm 0.111$ & $1.045 \pm 0.167$ \\
\hline
\end{tabular}

* significant difference of group 3 compared to group 1 and $2(\mathrm{P}<0.05)$.

\section{Results}

The MMP-13 expression corresponding to molecular weight $55 \mathrm{kDa}$ was expressed in all samples including healthy gingiva(Figure 1). In order to quantify the level of $\mathrm{MMP}-13$ in the groups, normalization to $\beta$-actin was performed(ratio of $\mathrm{MMP}-13 / \beta$-actin). $\mathrm{MMP}-13$

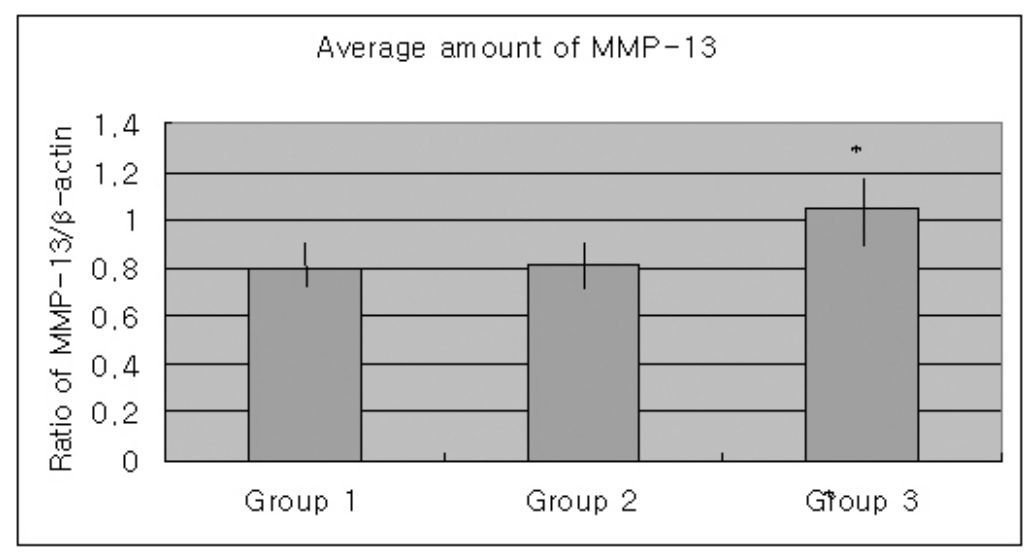

Figure. 2. The Graph showing the average amounts (Ratio of $M M P-13 / \beta$-actin) and standard deviation of gelatinase MMP-13 in group 1, 2 and 3.

In the group 3, MMP-13 seemed to be increased compared to group 1 and group 2 . And the difference was statistically significant $(P<0.05)$.

* significant difference of group 3 compared to group 1 and $2(P<0.05)$

Group 1 : healthy gingiva from systemically healthy person

Group 2 : inflammed gingiva from patient with chronic periodontitis

Group 3 : inflammed gingiva from patient with chronic periodontitis and type 2 DM 


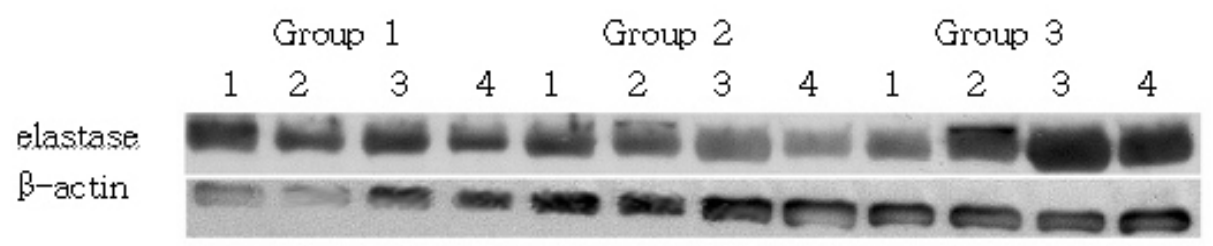

Figure. 3. The elastase expression levels showing 4 representative samples in each group. The elastase expression levels corresponding to molecular weight about $55 \mathrm{kDa}$ were shown in all samples including healthy gingiva and the expression levels of elastase were increased in group 1 than in group 2, 3. In order to quantify detected elastase, $\beta$-actin levels were also measured.

Group 1: healthy gingiva from systemically healthy person

Group 2 : inflammed gingiva from patient with chronic periodontitis

Group 3 : inflammed gingiva from patient with chronic periodontitis and type 2 DM

expression levels were given in Table 1 .

The mean amount of $\mathrm{MMP}-13$ expression (ratio of $\mathrm{MMP}-13 / \beta$-actin) in each 3 groups were $0.796 \pm 0.095,0.818 \pm 0.111,1.045 \pm$ 0.167 in group 1,2 and 3 . There were some tendencies that mean amount of MMP-13 was similar in inflamed gingiva of systemically healthy patient and normal gingiva but more increased in type 2 diabetic gingival tissue. That is, the amount of $\mathrm{MMP}-13$ was increased in group 3 compared to group 1 and 2 . And the difference was statistically significant $(\mathrm{P}<0.05)$.
The elastase expression level were detected at about $55 \mathrm{kDa}$ molecular weight in all three groups (Figure 3). The elastase expression level were expressed to be higher in group $1 \mathrm{com}^{-}$ pared to group 2 and 3. The expression level of group2 and 3 were similar. The elastase expression level were given in Table 2. The mean amounts of elastase (ratio of elastase/ $\beta$-actin) were $1.015 \pm 0.186$ in group $1,0.847 \pm 0.183$ in group 2 and $0.874 \pm 0.188$ in group 3 . The difference among 3 groups were not statistically significant $(\mathrm{P}>0.05)$.

Table 2. The elastase intensity was normalized by $\beta$-actin intensity to quantify the expression levels of elastase and the value were presented as a ratio of elastase/ $\beta$-actin

\begin{tabular}{cccc}
\hline Sample & Group 1 & Group 2 & Group 3 \\
\hline 1 & 0.951 & 0.924 & 0.779 \\
2 & 1.095 & 0.603 & 0.661 \\
3 & 1.063 & 1.160 & 0.746 \\
4 & 0.705 & 1.036 & 0.797 \\
5 & 1.350 & 0.832 & 0.751 \\
6 & 1.064 & 0.784 & 1.047 \\
7 & 1.017 & 0.725 & 1.200 \\
8 & 0.879 & 0.716 & 1.014 \\
\hline Mean \pm SD & $1.015 \pm 0.186$ & $0.847 \pm 0.183$ & $0.874 \pm 0.188$ \\
\hline
\end{tabular}




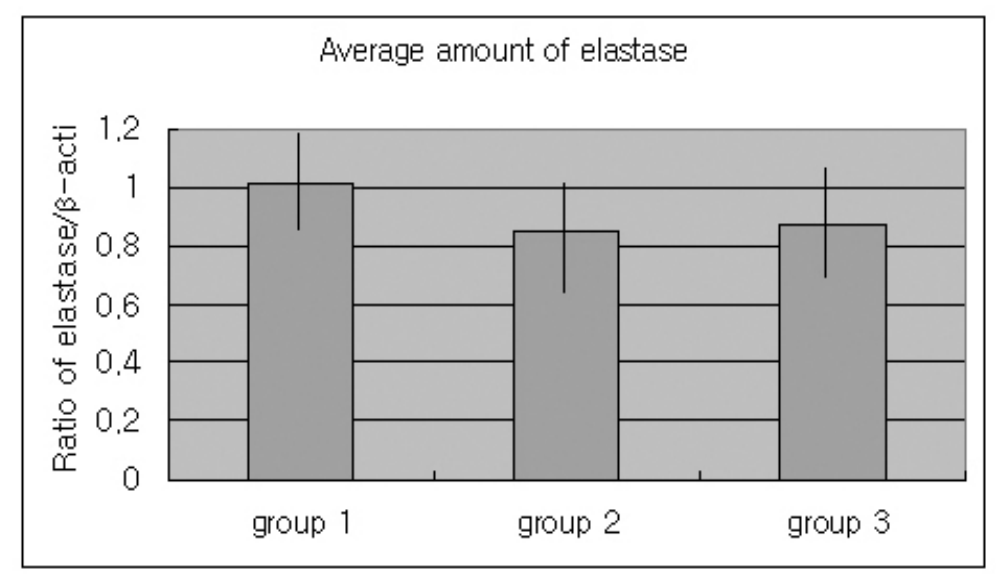

Figure. 4. The Graph showing the average amounts (Ratio of elastase/ $\beta$-actin) and standard deviation of elastase in group 1,2 and 3 .

In the group $2 \& 3$, the levels of elastase was lower compared to group 1 . The difference among three groups was not statistically significant $(P>0.05)$.

Group 1 : healthy gingiva from systemically healthy person

Group 2 : inflammed gingiva from patient with chronic periodontitis

Group 3 : inflammed gingiva from patient with chronic periodontitis and type 2 DM

\section{Discussion}

The purpose of this study was to quantify and compare the level of MMP-13 and elastase in the healthy, inflamed gingival tissue and inflamed gingival tissue associated with type 2 DM.

In situation of chronic hyperglycemia, secretion of proinflammatory cytokine increases and PMNL function, collagen production are $\mathrm{re}^{-}$ duced $^{4-8)}$. Inversely, inflammatory mediators can increase insulin resistance resulting in aggravation of DM by abnormal glucose metabolism $^{9-11)}$.

Periodontitis is infectious disease initiated by bacterial component and its metabolic products and characterized by the breakdown of collagenous extracellular matrices $(\mathrm{ECMs})^{12)}$. $\mathrm{ECM}$ is mainly consisted of collagen fiber and elastic fiber, and MMP-13, elastase are proteolytic enzyme of these two main fiber in gingiva.

Some studies discussed the interrelationship between periodontitis and MMP-13. Mancini et al. ${ }^{29)}$ reported that $\mathrm{MMP}-13$ can be expressed in vitro by stimulated gingival fibroblast and Tarvahartiala et al. ${ }^{30)}$ demonstrated that sulcular epithelial cell and macrophage like cell related to adult periodontitis lesion can synthesize $\mathrm{MMP}-13$ and protein.

But until now, few studies reports on the expression tendency of $\mathrm{MMP}-13$ in periodontitis patient associated to type $2 \mathrm{DM}$. In this study MMP-13 corresponding to molecular weight 55 $\mathrm{kDa}$ was exressed in most samples. The quantitative analysis of $\mathrm{MMP}-13$ level showed that MMP-13 expression was rather increased in inflamed gingiva associated to type $2 \mathrm{DM}$ compared to healthy gingiva and inflamed gingiva of systemically healthy patient. And the difference was statistically significant. This result 
indicates $\mathrm{MMP}-13$ reveals different response tendency in disease progression in type $2 \mathrm{DM}$ patient and plays role in part in increased inflammatory response of patient with this systemic disease.

In rat models of insulin-deficient diabetes, blockage of recepter for advanced glycation end-products(AGEs) diminished alveolar bone loss and decreased generation of proinflammatory cytokines such as $\mathrm{TNF}-\alpha$ and $\mathrm{L}-631$ ). Elevated level of blood glucose lead to the generation of largely irriversible AGEs and in diabetic condition, recepter for AGE on a range of cell types such as endothelial cells, monocytes, smooth muscle cells, and fibroblasts is increased. AGE and receptor interaction induces chemotaxis and increased generation of cytokines such as $\mathrm{TNF}-a, \mathbb{L}-1 \beta$, and $\mathbb{L}-6$ and these cytokines may induce increased MMP expression.

In this study, elastase expressions corresponding molecular weight about $55 \mathrm{kDa}$ were shown in more increased pattern in normal tis sue than inflamed tissue with and without type $2 \mathrm{DM}$ and mean amount of elastase in last two groups were similar.

Some studies report the close relationship between elastase and periodontal pathology. Eley and Cox32) reported during inflammation the amount of elastase increases in the interstitium of the periodontal tissue and in gingival crevicular fluid which may lead to tissue disintegration. Giannoupoulou et al.33) demonstrated that functional as well as antigenic elastase and its inhibitors significantly increase in GCF during the development of experimental gingivitis in human study. But most of these studies are conducted in GCF sample and little is known about expression pattern of elastase in gingival tissue. In this study, the elastase expressions were somewhat different from previous study. This may be due to different mechanism of elastase activity in the gingival tissue and GCF. As inflammatory process progresses, inflammatory product is released from gingival tissue to GCF. Therefore pathogenic pattern of these two sites can be different. But it was impossible to Figureure out the exact pathogenic mechanism of elastase in periodontitis, so further study to examine inflammatory response of elastase and other mediator in gingival tissue in needed.

In previous study, Chen et al.24) demonstrated positive correlation of $\mathrm{MMP}-8$ and elastase through GCF assay in chronic periodontitis patient. But they did not seem to show any close interrelationship when interrelationship between MMP-13 and elastase was analyzed in this study. In case of $\mathrm{MMP}-8$ and elastase, both proteinases are associated largely with neutrophils. But, MMP-13 is mainly expressed by chondrocytes, fibroblast, epithelial cells and other several tumor cells. So, pro-inflammatory cytokines such as $\mathrm{TNF}-a$, IL-6, IL -1 and other MMPs can be correlated to the expression of MMP-13 and elastase.

In conclusion, MMP-13 showed most increased expression tendency in inflamed tissue of type 2 DM patient, But elastase didn't show specific correlation with severity of gingival inflammation. And the interrelationship of MMP-13 and elastase was not significant between inflamed tissue of systemically healthy patient and patient with type 2 DM. To confirm exact pathologic mechanism of gingival inflammation of type $2 \mathrm{DM}$ patient, more study 
about relationship of elastase and other inflammatory mediator such as cytokine and other MMPs is needed and these studies seems to be able to contribute to the development of disease diagnosis methods and treatment modality.

\section{Summary}

The purpose of this study is to exam the difference of pathologic condition by comparing expression phase of MMP-13, elastase and to find out the relationship of two proteins in gingival tissue of chronic periodontitis patient and those with type 2 diabetes mellitus.

The marginal gingival tissue samples were obtained by intenal bevel incision at the time of periodontal surgery or tooth extraction. Gingival sample were divided into the three group which is healthy gingiva, inflamed gingiva from patients with chronic periodontitis and with chronic periodontitis associated to type 2 DM and each group ccomprised 8 samples. Tissue samples were prepared and analysed by western blotting. After that, quantification of MMP-13 and elastase was perfomed using a densitometer and statistically analyzed.

In the analysis of expression levels, mean amount of $\mathrm{MMP}-13$ was more increased in group 3 than group 1, 2. And the difference between group 3 and group 1,2 was statistically significant. The mean amount of elastase in inflamed tissue with and without type $2 \mathrm{DM}$ showed similar expression pattern. And MMP-13 and elastase didn't show any close interrelationship.

In conclusion, the expression level of MMP-13 was significantly increased in inflamed gingival tissue of patient with type $2 \mathrm{DM}$ and the interrelationship of $\mathrm{MMP}-13$ and elastase was not significant between inflamed tissue of systemically healthy patient and patient with type 2 DM.

\section{References}

1. Taylor GW, Burt BA, Becker MP et al. Non-insulin diabetes mellitus and alveolar bone loss progression over 2 years. J Periodontol, 1998;69:76-83.

2. Collin $\mathrm{H}-\mathrm{L}$, Uusitupa $\mathrm{M}$ and Niskanen L. Periodontal findings in elderly patient with non-insulin dependent diabetes mellitus. J Periodontol, 1998;69:962-966.

3. Emrich LJ, Shlossman $M$ and Genco RJ. Periodontal disease in non-insulin dependent diabetes mellitus. J Periodontol, 1991;62:123-132.

4. Brownlee M. Glycation product and the pathogenesis of diabetic complications. Diabetes care. 1992;15:1835-43.

5. Kerstein M. Receptor-specific induction of insulin-like growth factor I in human monocytes by advanced glycosylation end product-modified proteins. J Clin Invest. 1992;90:439-46.

6. Salvi GE, Lawrence HP, Offenbacher $\mathrm{S}$ and Beck JD. Influence of risk factors on the pathogenesis of periodontitis. Periodontol 2000. 1997;14:173-201.

7. Nelson RG, Shalossman M, Budding LM et al. Periodontal disease and NIDDM in Pima Indians. Diabetes Care. 1990;13:836-40.

8. Papapanou PN. Periodontal diseases: epidemiology. Ann Periodontol. 1996;1:1-36.

9. Joshi N, Caputo GM, Weitekamp MR and Karchmer AW. Infections in patients with diabetes mellitus. N Engl J Med. 
1999;341:1906-12.

10. Drobny BC, Abramson EC and Baumann G. Insulin receptors in acute infection: a study of factors conferring insulin resistance. J Clin Endocrinol Metab. 1984;58:710-6.

11. Taylor Gw, Burt BA, Becker MP et al. Severe periodontitis and risk for poor glycemic control in patients with non-insulin-dependent diabetes mellitus. J Periodontol. 1996;67:1085-93.

12. Ejeil AL, Igondjo-Tchen S, Ghomarasseni S et al. Expression of matrix metalloproteinases(MMPs) and tissue inhibitors of metalloproteinases(TIMPs) in healthy and diseased human gingiva. Periodontol. 2003;74:188-195.

13. Ryan EM and Golub LM : Modulation of matrix metalloproteinase activities in periodontitis as a treatment strategy. Periodontology 2000, 2000;24:226-238.

14. Souza AP, Gerlach RF and Line SRP. Inhibition of human gingival gelatinases (MMP-2 and MMP-9) by metal salts. Dental Materials, 2000;16:103-108,

15. Listgarten MA. Pathogenesis of periodontitis. J Clin Periodontol. 1986;13:418- 425.

16. Uitto VJ, Christopher M and Overall and Cristopher McCulloch. Proteolytic host cell enzymes in gingival crevice fluid. Periodontol 2000. 2003 31:77-104.

17. Nagase $\mathrm{H}$ and Woessner JF Jr. Matrix metalloproteinases. J Biol Chem. 1999;274: 21491-21494.

18. Wincenti MP. The matrix metalloproteinase(MMP) and tissue inhibitor of metalloproteinase genes. Methods Mol Biol. 2001;151:121-148.

19. Uitto VJ, Airola K, Vaalamo $\mathrm{M}$ et al.
Collagenase -3 (matrix metalloproteinase-13) expression is induced in oral mucosal epithelium during chronic inflammation. Am J Pathol. 1998;152:1489-1499.

20. Wahlgren J, Maisi P, Sorsa $\mathrm{T}$ et al. Expression and induction of collagenases $(\mathrm{MMP}-8$ and -13$)$ in plasma cells associated with bone-destructive lesions. J Pathol. 2001;194:217-224.

21. Kiili M, Cox SW, Chen HW et al. Collagenase $-2(\mathrm{MMP}-8)$ and collagenase -3 (MMP-13) in adult perioodntitis: molecular forms and levels in gingival crevicular fluid and immunolocalisation in gingival tissue J Clin Periodontol. 2002;29:224-232.

22. Eley BM and Cox SW. Advances in periodontal diagnosis. 7. Proteolytic and hydrolytic enzymes link with periodontitis. British Dental Journal. 1998;184:323-328.

23. Jin LJ, Leung WK, Corbet EF and Söder B. Relationship of changes in interleukin-8 levels and granulocyte elastase activity in gingival crevicular fluid to subgingival periodontopathogens following non- surgical periodontal therapy in subjects with chronic periodontitis. J Clin Periodontol. 2002;20:604-614.

24. Chen HY, Cox SW, Eley BM et al. Matrix metalloproteinase -8 levels and elastase activities in gingival crevicular fluid form chronic adult periodontitis patients. J Clin Periodontol. 2000;27:366-369.

25. Kang MG, Cha HJ, Song SH et al. MMP-2, MMP-8 expression in gingival tissue of chronic periodontitis associated to type 2 diabetes mellitus. the Journal of Koran Academy of Periodontology. 2005;35: 661-674.

26. Muhlemann HR and Son S. Gingival sulcus 
bleeding a leading symptom in initial gingivitis. Helv Odontol Acta 1971;15:107.

27. Amitage GC. Development of a classification system for periodotal diseases and conditions. Ann Periodontol 1999;4:1-6.

28. Cho J-Y, Xing S, LIu X et al. Expression and activity of human $\mathrm{Na}+/ \mathrm{I}^{-}$symporter in human glioma cells by adenovirus-mediateed gene delivery. Gene Therapy. 2000;7:740-749.

29. Mancini S, Romanelli R, Laschinger CA et al. Assessment of a novel screening test for neutrophil collagenase activity in the diagnosis of periodontal diseases. J Periodontol. 1999;70:1292-1302.

30. Tervahartiala T, Pirilä E, Ceponis A et al. The in vivo expression of the collagenolytic matrix metalloproteinase(MMP-2,-8,-13 and -14) and matrilysin(MMP-7) in adult and localized juvenile periodontitis. J Dent Res. 2000;79:1969-1977.

31. Lalla E, Lamster IB, Feit $M$ et al Blockade of RAGE suppresses periodontitis - associated bone loss in diabetic mice. $\mathrm{J}$ Clin Invest, 2000;105:1117-1124,

32. Eley BM and Cox SW. Cathepsin B/L-, elastase-, tryptase-, trypsin- and dipeptidyl peptidase $\mathrm{IV}$-like activities in gingival crevicular fluid: correlation with clinical parameters in untreated chronic periodontitis patients. J Peridontal Res. 1992;27:62-69.

33. Giannopoulou C, Anderson E, Demeurisse C and Cimasoni G. Neutrophil elastase and its inhibitors in human gingival crevicular fluid during experimental gingivitis. J Dent Res. 1992;71:359-363. 
-Abstract-

\section{2형 당뇨병을 동반한 만성 치주염 환자의 치은조직에서 Matrix Metalloproteinse-13과 elastase의 발현 양상 비교}

박현규, 이재목

경북대학교 치의학대학원 치주과학교실

치주질환은 치아 지지조직의 파괴로 특정 지어지는 감염성 질환으로서 이것은 주로 조직의 교원질 성분을 분해시키는 $\mathrm{MMP}$ (matrix metalloproteinase)에 의해 이루어진다.

한편, 여러 연구에서 당뇨병과 치주질환의 심도와의 관계에 대한 논의가 있어왔으며 당뇨병이 치주염을 포 함한 구강 감염에 대한 감수성를 증가시키며 역으로 만성 치주염의 염증성 매개물질에 의해 인슐린 작용이 방 해받을 수 있음을 보고하였다.

본 연구의 목적은 만성 치주염 환자와 제 2형 당뇨병을 동반한 만성 치주염 환자의 치은조직에서 $\mathrm{MMP}-13$ 과 elastase의 발현 양상을 비교하여 병리 기전의 차이점을 규명하고, 두 단백질간의 상호관계를 알아보기 위 한 것이다.

경북대 병원 치주과에 내원한 환자의 비당뇨 환자의 정상 치은 부위, 비당뇨 환자의 만성 치주염 부위, 제 2 형 당뇨병 환자의 만성 치주염 부위에서 각각 8개의 변연 치은을 채득하여 액화 질소에 급속 동결시켰다. 모든 조직 샘플에서 동량의 단백질을 western blotting을 통해 분석하였고, densitometer를 이용하여 정량한 후 ANOVA 분석으로 통계처리 하였다.

결과분석에서 $\mathrm{MMP}-13$ 은 제 2 형 당뇨를 가진 환자의 염증성 조직에서 가장 높게 발현되었고 전신적으로 건 강한 환자의 염증성 조직과 정상 조직에서는 유사한 양상을 보였으며 그 차이는 통계적으로 유의하였다. 또한 elastase는 그룹간에 유의한 차이 없이 유사한 양상으로 발현되었고 염증성 조직에서도 당뇨병의 유무에 관계 없이 유사하게 나타났다. 한편 조직내 $\mathrm{MMP}-13$ 과 elastase의 발현 양상간에 유의한 상관관계는 보이지 않았 다.

결론적으로 $\mathrm{MMP}-13$ 은 당뇨병을 동반한 환자의 치은 염증조직에서 유의하게 증가되어 나타났으며, 전신적 으로 건강한 환자의 염증조직과 당뇨를 동반한 환자의 염증조직에서 $\mathrm{MMP}-13$ 과 elastase의 발현양상은 큰 상 관관계가 발견되지 않았다. 